\title{
ANALISIS PORTOFOLIO OPTIMAL SAAT TERJADINYA KRISIS KEUANGAN GLOBAL PADA SEKTOR PERBANKAN YANG TERCATAT DI BURSA EFEK INDONESIA TAHUN 2007- 2010
}

\author{
Patricius Josef Parikesit \\ Sekolah Tinggi Ilmu Ekonomi Pancasetia Banjarmasin \\ Jl. A Yani Km. 5,5 Banjarmasin, Kalimantan Selatan \\ e-mail :pj.parikesit@gmail.com
}

\begin{abstract}
This Journal was done to knows the magnitude of the different levels of return and risk portfolio optimal formed of bank stocks listed on the Indonesia Stock Exchange before and during the Global Financial Crisis years 2007-2010. Objects on this research is bank stocks listed on the the Indonesia Stock Exchange (January 2007 - December 2010). The samples of this study gathered 19 consistent bank stocks listed on the the Indonesia Stock Exchange, and The samples of this study is stocks which were consistent on Indonesia Stock Exchange, active to trading on Indonesia Stock Exchanges and available complete in January 2007 - Desember 2010. Optimum portfolio by using Single Index Model formed During the Global Financial crisis produce has made Portfolio Return is $1.87 \%$ and Portfolio Risk is $5.29 \%$.
\end{abstract}

Keywords: Optimum Stock Portfolio, Single Index Model, Global Financial Crisis.

Abstrak: Jurnal ini dilakukan untuk mengetahui tingkat return dan risiko portofolio optimal yang dibentuk dari saham-saham perbankan yang terdaftar di Bursa Efek Indonesia Saat terjadinya Krisis Keuangan Global tahun 2007-2010. Objek pada jurnal ini adalah sahamsaham perbankan yang terdaftar di Bursa Efek Indonesia tahun Januari 2007 - Desember 2010. Sampel yang diperoleh sebanyak 19 saham perbankan yang konsisten terdaftar di Bursa Efek Indonesia, dan data diperoleh dari saham yang aktif melakukan transaksi perdagangan di Bursa Efek Indonesia serta tersedia lengkap periode Januari 2007 - Desember 2010. Perbedaan Portofolio optimal yang dibentuk menggunakan Model Indeks Tunggal saat terjadinya krisis keuangan global Return portofolio (Ri) yang dihasilkan sebesar $1.87 \%$ dengan risiko portofolio (E(Ri)) sebesar $5.29 \%$.

Kata kunci: Portofolio Optimal Saham, Model Indeks Tunggal, Krisis Keuangan Global.

\section{Latar Belakang}

Jurnal ini dibuat untuk mengetahui besarnya perbedaan tingkat Return dan resiko Portofolio optimal yang dibentuk dari saham-saham perbankan yang terdaftar di Bursa Efek Indonesia saat terjadinya Krisis Keuangan Global.

Peristiwa krisis keuangan yang terjadi di Amerika Serikat adalah peristiwa dimana sektor perekonomian negara adidaya Amerika Serikat mengalami guncangan yang berawal dari pemberian kedit murah perumahan (Subprime Mortgages) bagi debitur, tetapi karena kurangnya pengawasan dari pemerintah dan lembaga keuangan di Amerika Serikat, maka terjadi kegagalan pembayaran (kredit macet) oleh para debitur tersebut. Perekonomian dunia mengalami gejolak disebabkan dari efek krisis keuangan yang terjadi di Amerika Serikat dan mempengaruhi negara lain di seluruh dunia.

Sektor Pasar Modal di Indonesia sendiri juga terkena dampak krisis keuangan global mulai pada tahun 2008 tepatnya pada bulan Januari 2008. Pada akhir bulan Januari 2008 pasar modal dikejutkan dengan pengungkapan kerugian Citybank sekitar 30\% akibat dari kasus Subprime Mortgage di Amerika Serikat (Jogiyanto,2009). Subprime Mortgage merupakan kredit perumahan berisiko tinggi di Amerika Serikat, kredit ini diberikan kepada para nasabah dengan posisi 
keuangan mereka yang kurang sehat dan akad kredit ini kemudian dijaminkan kembali kepada perusahaan keuangan untuk mendapatkan pinjaman uang kembali.

Akibat dari peminjam kredit merupakan nasabah - nasabah kurang sehat keuangannya, maka banyak terjadi kredit macet sehingga menimbulkan kerugian yang besar pada beberapa investmen bank dan hedge fun. Akibat lebih lanjutnya, mereka menarik portofolio di pasar modal seluruh dunia yang mengakibatkan kejatuhan nilai indeks pasar modal seluruh dunia, salah satunya IHSG (Indeks Harga Saham Gabungan).

Pelemahan pertumbuhan ekonomi memberikan tekanan cukup besar bagi kinerja keuangan. Perbankan sebagai sektor penting dalam menghimpun dan menyalurkan dana juga mendistribusikan uang ke berbagai sektor di Indonesia diharapkan mampu menjaga stabilitas ekonomi dengan lebih bijak dalam menjaga nilai tukar dan tingkat suku bunga agar perekenomian di Indonesia dapat terjaga dan tetap meyakinkan investor bahwa berinvestasi pada sektor keuangan dapat memberikan keuntungan baik jangka pendek maupun jangka panjang.

Analisis investasi sering menjadi masalah yaitu tentang penafsiran risiko yang dihadapi oleh investor. Teori keuangan menjelaskan bahwa apabila tingkat risiko meningkat, maka tingkat keuntungan yang diisyaratkan oleh investor akan meningkat. Sehingga untuk meminimalisir risiko saham maka investor dapat berinvestasi dalam berbagai jenis saham dan membentuk portofolio (Fabozzi,1999).

Instrumen investasi tersebut meliputi saham, obligasi, valas, deposito, indeks harga saham, produk derivatif lainnya (Samsul,2006). Dalam berinvestasi, perlu juga adanya pertimbangan bahwa tidak selalu keuntungan yang besar yang diperoleh akan tetapi, tingkat keuntungan yang diharapkan juga disertai dengan tingkat risiko yang beragam baik itu risiko yang bersifat sistematik maupun risiko yang tidak bersifat sistematik.

Menurut Jogiyanto (2003), return dan risiko merupakan dua hal yang tidak terpisah.
Return dan risiko mempunyai hubungan yang positif, semakin besar risiko yang harus ditanggung, semakin besar return yang akan diperoleh. Maka dari itu, berinvestasi pada aset dengan risiko yang kecil, return yang akan diperoleh juga kecil. Risiko pada suatu sekuritas tidak dapat sepenuhnya dihilangkan, akan tetapi, risiko dapat diminimalisir dengan melakukan diversifikasi. Diversifikasi ini dapat dilakukan dengan tidak menurunkan keuntungan (return) yang diharapkan. Investor dapat melakukan diversifikasi dengan cara membentuk portofolio optimal (Jogiyanto,2003). Portofolio juga diartikan sebagai kombinasi beberapa aktiva yang diinvestasikan oleh investor, baik perorangan maupun institusi. Dalam pasar modal, portofolio dikaitkan dengan portofolio aktiva finansial yaitu kombinasi beberapa saham sehingga investor dapat memperoleh return optimal dan memperkecil risk (Sumariyah,1997). Menurut Elton dan Gruber (1997) analisis portofolio berkenaan dengan keinginan memperoleh sekuritas untuk dimiliki.

Penelitian ini mengoptimalkan tingkat pengembalian yang diharapkan dengan tingkat risiko yang minimum dengan menekan risiko tersebut seminimal mungkin sebelum dan saat krisis keuangan terjadi. Berdasarkan latar belakang maka menarik untuk dilakukan penelitian tentang hal ini yang berjudul "Analisis Portofolio Optimal Saham Sektor Perbankan yang Tercatat di Bursa Efek Indonesia Saat Terjadinya Krisis Keuangan Global Tahun 2007-2010”.

Rumusan Masalah penelitian ini adalah "Mengetahui Return dan Resiko Portofolio Optimal Saham saat terjadi krisis keuangan global pada sektor perbankan di Indonesia" Tujuan penelitian ini berdasarkan latar belakang dan rumusan masalah maka tujuan penelitian ini adalah "Untuk Mengetahui saham-saham yang memberikan return yang maksimal dan resiko yang minimal saat terjadinya krisis keuangan global terhadap pembentukan portofolio optimal saham pada sektor perbankan".

Kerangka Pikir. Model indeks tunggal digunakan untuk membentuk portofolio optimal saham saat terjadinya Krisis 
Keuangan Global. Maka kerangka pikir yang digunakan dalam penelitian seperti yang terlihat pada gambar 1 .

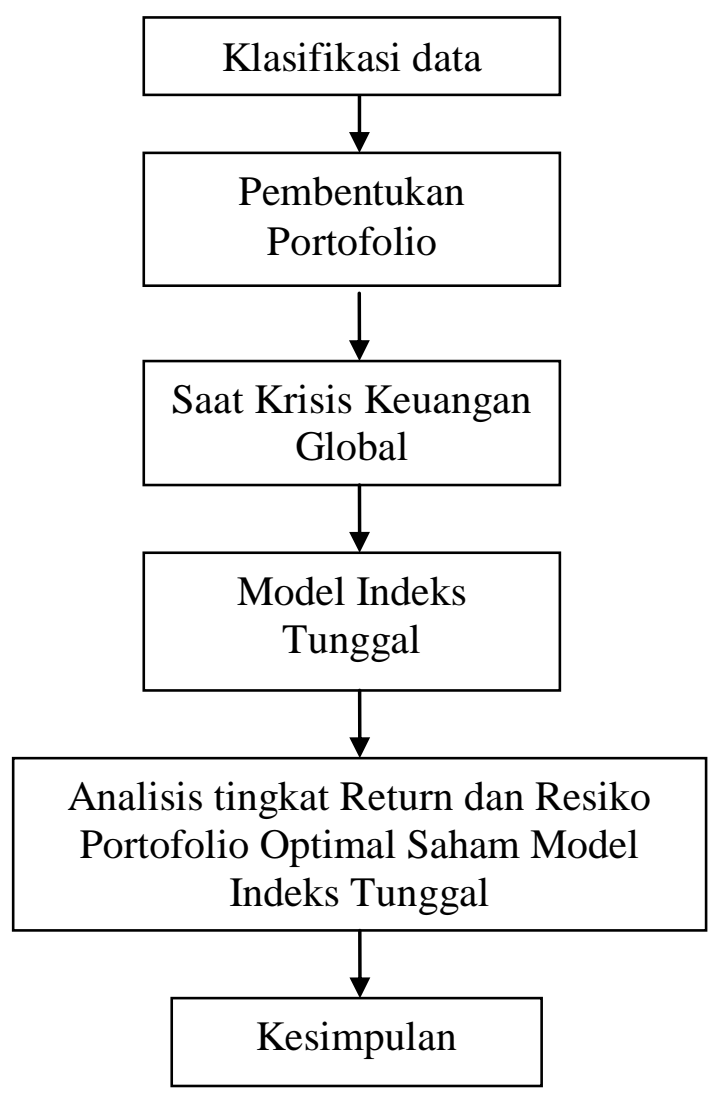

\section{Gambar 1. Kerangka Pikiran}

\section{Metode Penelitian}

Jenis penelitian yang dilakukan pada Jurnal ini adalah penelitian deskriptif kuantitatif yang dilakukan untuk mengetahui dan menjelaskan variabel yang diteliti dalam suatu situasi dengan data yang diperoleh dari Bursa Efek Indonesia dengan mengambil harga saham pada saat penutupan pada periode saat terjadinya krisis keuangan berskala global sejak tahun 2007 hingga tahun 2010.

Objek penelitian ini adalah saham pada sektor perbankan, yaitu 32 perusahaan perbankan yang terdapat di Indonesia dan yang tercatat di Bursa Efek Indonesia periode 2007 -2010 dan perbankan yang terpilih untuk membentuk portofolio optimal dilihat melalui data perdagangan saham pada saat penutupan (Closing Price). Objek yang diteliti pada penelitian ini adalah saham perbankan yang tercatat di di Bursa Efek
Indonesia tahun 2007-2010, seperti ditunjukkan pada Tabel 1 .

Teknik analisis pembentukan portofolio optimal dengan model indeks tunggal adalah menganalisis sekuritas dengan menggunakan rasio excess return to beta (ERB). Analisis dilakukan dengan menghitung koefisien beta yang mencerminkan tingkat risiko dan tingkat return masing-masing sekuritas yang diamati, dengan diketahuinya tingkat return saham dan koefisien beta. Nilai ERB kemudian dibandingkan dengan nilai Cut-off Rate (Ci). Cut-off Rate (Ci) merupakan perbandingan antara varian return pasar dengan return sekuritas individu terhadap varian errors sekuritas. Sekuritas-sekuritas yang memiliki nilai ERB lebih besar dari pada nilai Cut-off Rate (Ci) akan menjadi kandidat porofolio optimal saham, sedangkan sekuritas-sekuritas yang nilai ERB lebih kecil daripada nilai Cut-off Rate (Ci), tidak dapat dimasukkan kedalam kandidat portofolio optimal saham dan nilai Cut-off Rate (Ci) yang paling besar disebut Cut-off Point (C*). Analisis portofolio optimal saham perbankan saat terjadinya krisis keuangan global dengan Model Indeks Tunggal dengan menggunakan Microsoft Excel 2010.

Saham perbankan dijadikan sebagai objek penelitian karena karena merupakan sektor penting bagi Indonesia untuk tetap menjaga stabilitas ekonomi di Indonesia dan bank sangat terkait dengan penyediaan modal bagi usaha atau perdagangan, sehingga perekonomian dapat berputar dan agenda liberalisasi menuju target sasaran, yakni sektor perbankan.

Selain itu, perkembangan harga saham sektor perbankan pada Bursa Efek Indonesia pada periode sebelum krisis keuangan global mengalami pasang surut, pasalnya banyak analisis dari pengamat ekonomi memperkirakan bahwa akan terjadi krisis keuangan global dan resesi ekonomi dunia akan terasa pada tahun berikutnya, dan benar saja dampak dari krisis keuangan global memberikan sentimen buruk bagi lembaga keuangan bank dan non bank di Indonesia. 
Tabel 1. Daftar Perbankan Tercatat di Bursa Efek Indonesia Tahun 2007-2010

\begin{tabular}{clll}
\hline No & \multicolumn{1}{c}{ Nama Bank } & & \\
\hline 1 & PT. Bank Mandiri, Tbk & 17 & PT. Bank BPD Jawa Barat dan Banten, Tbk \\
2 & PT. Bank Rakyat Indonesia, Tbk & 18 & PT. Bank BPD Jawa Timur, Tbk \\
3 & PT. Bank Central Asia, Tbk & 19 & PT. Bank QNB Kesawan, Tbk \\
4 & PT. Bank Negara Indonesia, Tbk & 20 & PT. Bank Bumi Arta. Tbk \\
5 & PT. Bank CIMB Niaga, Tbk & 21 & PT. Bank Sinarmas, Tbk \\
6 & PT. Bank Danamon Indonesia, Tbk & 22 & PT. Bank Of India Indonesia, Tbk \\
7 & PT. Pan Indonesia Bank, Tbk & 23 & PT. Bank Tabungan Pensiunan Nasional, Tbk \\
8 & PT. Bank Permata, Tbk & 24 & PT. Bank Victoria Internasional, Tbk \\
9 & PT. Bank International Indonesia, Tbk & 25 & PT. Bank Artha Graha Internasional, Tbk \\
10 & PT. Bank Tabungan Negara, Tbk & 26 & PT. Bank Mayapada Internasional, Tbk \\
11 & PT. Bank ICB Bumiputera, Tbk & 27 & PT. Bank Wingu Kentjana Internasional, Tbk \\
12 & PT. Bank Capital Indonesia, Tbk & 28 & PT. Bank Mega, Tbk \\
13 & PT. Bank Ekonomi Raharja, Tbk & 29 & PT. Bank OCBC NISP, Tbk \\
14 & PT. Bank Nusantara Parahyangan, Tbk & 30 & PT. Bank Himpunan Saudara 1906, Tbk \\
15 & PT. Bank Mutiara, Tbk & 31 & PT. Bank Rakyat Indonesia Agroniaga, Tbk \\
16 & PT. Bank Pundi Indonesia, Tbk & 32 & PT. Bank Bukopin, Tbk \\
\hline Sumb
\end{tabular}

Sumber : IDX Statistik 2010

Model Indeks Tunggal. William Sharpe (1963) mengembangkan model yang disebut dengan model indeks tunggal (singleindex model). Model ini dapat digunakan untuk menyederhanakan perhitungan pada model Markowitz dengan menyediakan parameter- parameter input yang dibutuhkan di dalam perhitungan model Markowitz. Disamping itu, model indeks tunggal dapat juga digunakan untuk menghitung return ekspektasi dan risiko portofolio (Jogiyanto,2003). Indeks tunggal dikembangkan sebagai penyempurnaan dari model Markowitz, dimana dalam model Indeks Tunggal investor mempunyai banyak pilihan untuk memasukkan aktiva bebas risiko dalam portofolio. Model ini beranggapan bahwa harga dari suatu sekuritaas selalu fluktuatif searah dengan indeks harga pasar. Model ini disebut Sharpe single indeks model karena dikembangkan oleh William Sharpe (1963) dan digunakan untuk memperkirkan hasil return berbagai sekuritas individual maupun portofolio. Model Indeks Tunggal dapat dirumuskan sebagai berikut :

$\mathrm{Ri}=\alpha+\beta \cdot \mathrm{RM}+\varepsilon \mathrm{i}$

Di mana: $\mathrm{Ri}=$ return saham, $\mathrm{Rm}=$ return pasar, $\alpha=$ konstanta yang merupakan titik potong garis regresi dengan sumbu vertikal, dan $\beta=$ slope garis regresi.
Langkah-langkah perhitungan dengan Model Indeks Tunggal adalah :

1. Expected Return $\left(R_{t}\right)$

Sebelum mencari nilai expected return $\left(R_{t}\right)$, maka terlebih dahulu dicari nilai return saham individu ( $\mathrm{Ri}$ ) untuk saham kandidat portofolio berdasarkan harga saham bulanan selama periode observasi, setelah didapat $\mathrm{Ri}$ maka expected return dapat diketahui dengan persamaan berikut ini:

$\mathrm{E}(\mathrm{Ri})=\frac{2 \mathrm{Rij}}{\mathrm{N}}$

Keterangan:

$\mathrm{E}(\mathrm{Ri})=$ Tingkat keuntungan yang diharapkan dari investasi

Rij = Tingkat keuntungan saham individu $\mathrm{N}=$ Jumlah periode investasi.

2. Tingkat bunga bebas risiko (Rf).

Risk Free (Rf) dicari dan dihitung dari data Suku Bunga SBI. Hal ini berdasarkan asumsi bahwa kemungkinan risiko BI tidak membayar bunga sangat kecil.

3. Standar Deviasi $\sigma$ digunakan untuk mengukur risiko dari realized return, yang dapat dihitung dengan program Microsoft Excel menggunakan rumus STDEV. 
$\mathrm{SD}=\sum_{\mathrm{t}=1}^{\mathrm{n}} \frac{(x i-x)^{2}}{n-1}$

Keterangan:

$\sigma=$ standar deviasi

$\mathrm{Xi}=$ realized return saham $-\mathrm{i}$

$\mathrm{X}=$ rata-rata realized return saham $\mathrm{i} \mathrm{n}=$ jumlah realized return saham-i

4. Variance $\left(a^{2} i\right)$ digunakan untuk mengukur risiko expected return saham-i. Variance dapat dihitung dengan cara, yaitu mengkuadratkan standar deviasi atau dihitung dengan program Microsoft Excel menggunakan rumus $V A R$ atau menggunakan rumus:

$\operatorname{Var}=a^{2} i$

5. Beta $\beta \mathrm{i}$ adalah risiko dari saham individual, menghitung keserongan (slope) realized return suatu saham dengan realized return pasar (IHSG) dalam periode tertentu. Beta digunakan untuk menghitung Excess Return to Beta (ERB) dan Beta yang diperlukan untuk menghitung Cut-Off Point (Ci). Beta dapat dihitung dengan program Microsoft Excel menggunakan rumus Slope.

$\beta \mathrm{i}=\left(\frac{\sigma_{\mathrm{i}}}{\sigma_{\mathrm{m}}}\right) \eta_{\mathrm{im}}$

Keterangan:

$\beta \mathrm{i}=$ beta saham $-\mathrm{i}$

$\sigma \mathrm{i}=$ standar deviasi saham $-\mathrm{i}$

$\sigma \mathrm{m}=$ standar deviasi pasar

$r_{\mathrm{Im}}=$ korelasi realized return saham 5

dengan realized return pasar

6. Nilai Alpha Index (Ai) dihitung untuk mendapatkan nilai $\mathrm{Ai}$, dan Beta (Bi) dihitung untuk mendapatkan nilai Beta $\mathrm{Bi}$, keduanya diperlukan untuk menghitung nilai Cutt-off Rate (Ci). Penentuan nilai Ai dan Bi untuk masing saham ke-i sebagai berikut:

$$
\mathrm{A}_{\mathrm{i}}=\frac{\left[E\left[R_{\mathrm{i}}\right]-R_{f j}\right] \beta_{\mathrm{i}}}{\sigma e \mathrm{i}^{2}}
$$

$\beta_{\mathrm{i}}$ dicari dengan persamaan: $\beta_{i}=\frac{\beta_{i}^{2}}{\sigma e i_{i}^{2}}$

$\mathrm{E}(\mathrm{Ri})=$ expected return saham ke- $\mathrm{i}$

$\mathrm{Rf}=$ risk free rate of return

$\beta_{\mathrm{i}}=$ beta saham ke- $\mathrm{i}$

$\sigma e i=$ variance saham ke-i (unique risk).

7. Cut-Off Rate (Ci) merupakan nilai $\mathrm{C}$ untuk saham ke-i yang dihitung dari akumulasi nilai- nilai Ai sampai dengan $\mathrm{Ai}$ dan nilai-nilai $\mathrm{Bi}$ sampai dengan $\mathrm{Bi}$. Nilai $\mathrm{Ci}$ merupakan hasil bagi varian pasar dan return premium terhadap variance error saham dengan varian pasar dan sensitivitas saham individual terhadap variance error saham

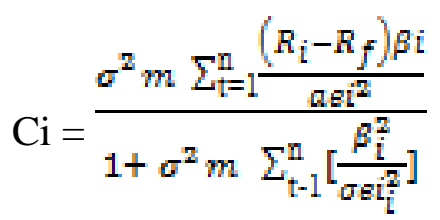

Keterangan:

$\mathrm{cr}^{2} \mathrm{~m}=$ variance realized return pasar (IHSG)

8. Cut-Off Point $\left(\mathrm{C}^{*}\right)$ merupakan nilai $\mathrm{Ci}$ terbesar dari sederetan nilai $\mathrm{Ci}$ saham, dihitung dengan program Microsoft Excel menggunakan rumus $M A X$.

9. Pembentukan Portofolio Saham. Sahamsaham yang akan dimasukkan dalam pembentukan portofolio optimal adalah saham-saham yang nilai ERBnya lebih besar dari nilai cut off point $\left(\mathrm{C}^{*}\right)$. Nilai cut off point $\left(\mathrm{C}^{*}\right)$ ditentukan berdasarkan nilai ERB terakhir yang masih lebih besar dari nilai cut off rate $(\mathrm{Ci})$.

10. Menghitung Proporsi Dana. Proporsi dana pada masing-masing saham yang masuk dalam pembentukan portofolio optimal dihitung dengan rumus berikut:

$X i=\frac{Z j}{\sum_{j=1}^{N} Z j}$

Dimana:

$\mathrm{X} \mathrm{i}=$ Proporsi saham $-\mathrm{i}$ 
11. Expected return portofolio $\mathrm{E}\left(\mathrm{R}_{\mathrm{p}}\right)$ merupakan rata-rata tertimbang dari return individual masing-masing saham pembentuk portofolio, dihitung dengan menggunakan rumus:

$\mathrm{E}\left(\mathrm{R}_{\mathrm{p}}\right)=\sum_{\mathrm{i}-1}^{\mathrm{n}} X_{1}, E\left(R_{\mathrm{i}}\right)$

Keterangan:

$\mathrm{E}(\mathrm{Rp})=$ Expected Return portofolio

$\mathrm{Xi}=$ proporsi dana saham ke- $\mathrm{i}$

$\mathrm{E}(\mathrm{Ri})=$ Expected Return saham ke-i

12. Risiko atau standar deviasi portofolio merupakan rata-rata tertimbang dari standar deviasi individual masingmasing saham pembentuk portofolio, dihitung dengan menggunakan rumus:

$\sigma_{\rho}=\sum_{i-1}^{n} X_{1}, \sigma_{i}$

13. Solver merupakan aplikasi dalam Microsoft Excel yang berfungsi untuk meminimalisasi risiko portofolio optimal saham dengan tingkat return tertentu. Solver dapat digunakan setelah portofolio optimal saham telah dilakukan dan menghasilkan tingkat return dan risiko tertentu. Penggunaan solver yaitu dengan memasukkaan hasil dari perhitungan return dan risiko portofolio optimal saham dan tingkat proporsi dana tiap saham perbankan. Tujuan dalam membentuk portofolio optimal adalah mendapat return tertentu dengan tingkat risiko yang rendah, maka dalam penggunaan solver memiliki tujuan untuk meminimalkan tingkat risiko seminimal mungkin.

\section{Hasil Penelitian dan Pembahasan}

Tabel 2 menunjukkan pemeringkatan saham berdasarkan nilai ERB. Nilai ERB dihitung untuk mengukur tingkat return terhadap suatu risiko individu yang tidak dapat di diversifikasi (Beta). Pada tabel diatas saham BABP (PT.Bank ICB Bumiputera,tbk) berada di peringkat atas dengan nilai 1.0341 hal itu berarti saham BABP merupakan saham dengan kinerja terbaik dibandingkan dengan saham-saham lainnya.

Tabel 2. Perhitungan nila ERB Saat Krisis Keuangan Global Terjadi (tahun 20072010).

\begin{tabular}{ccccccc}
\hline No & Saham & $\overline{\mathbf{R}}_{\mathbf{1}}$ & $\mathbf{R}_{\mathbf{F}}$ & $\overline{\mathbf{R}}_{\mathbf{1}}-\mathbf{R}_{\mathbf{F}}$ & $\boldsymbol{\beta}_{\mathbf{1}}$ & ERB \\
\hline 1 & BABP & 0.0252 & 0.0001 & 0.0251 & 0.0243 & 1.0341 \\
\hline 2 & BEKS & 0.0156 & 0.0001 & 0.0155 & 0.0560 & 0.2765 \\
\hline 3 & NISP & 0.0188 & 0.0001 & 0.0187 & 0.1051 & 0.1776 \\
\hline 4 & MEGA & 0.0193 & 0.0001 & 0.0192 & 0.1087 & 0.1768 \\
\hline 5 & BKSW & 0.0086 & 0.0001 & 0.0085 & 0.0545 & 0.1556 \\
\hline 6 & BBCA & 0.0202 & 0.0001 & 0.0201 & 0.2018 & 0.0999 \\
\hline 7 & BMRI & 0.0221 & 0.0001 & 0.0220 & 0.2733 & 0.0805 \\
\hline 8 & BBNI & 0.0245 & 0.0001 & 0.0244 & 0.3223 & 0.0757 \\
\hline 9 & BNGA & 0.0158 & 0.0001 & 0.0158 & 0.2234 & 0.0705 \\
\hline 10 & INPC & 0.0097 & 0.0001 & 0.0096 & 0.1740 & 0.0550 \\
\hline 11 & BVIC & 0.0049 & 0.0001 & 0.0048 & 0.0950 & 0.0509 \\
\hline 12 & BBRI & 0.0184 & 0.0001 & 0.0183 & 0.3693 & 0.0496 \\
\hline 13 & PNBN & 0.0077 & 0.0001 & 0.0076 & 0.1571 & 0.0484 \\
\hline 14 & BNLI & 0.0147 & 0.0001 & 0.0146 & 0.3743 & 0.0391 \\
\hline
\end{tabular}

Sumber : Data Diolah, 2016 
Tabel 3. Perhitungan Cut-off Rate dan Penyeleksian Obligasi pada Model Indeks Tunggal

\begin{tabular}{rrrrrr}
\hline \multicolumn{1}{l}{ No. } & Saham & Ai & Bi & Ci & ERB \\
\hline 1 & BABP & 0.0001 & 1.0001 & 0.0001 & 0.1776 \\
\hline 2 & BEKS & 0.0002 & 1.0008 & 0.0002 & 1.0341 \\
\hline 3 & NISP & 0.0006 & 1.0032 & 0.0006 & 0.2765 \\
\hline 4 & MEGA & 0.0016 & 1.0089 & 0.0016 & 0.1768 \\
\hline 5 & BKSW & 0.0004 & 1.0024 & 0.0004 & 0.1556 \\
\hline 6 & BBCA & 0.0038 & 1.0377 & 0.0036 & 0.0999 \\
\hline 7 & BMRI & 0.0031 & 1.038 & 0.0029 & 0.0805 \\
\hline 8 & BBNI & 0.0025 & 1.0331 & 0.0024 & 0.0757 \\
\hline 9 & BNGA & 0.0015 & 1.0212 & 0.0015 & 0.0705 \\
\hline 10 & INPC & 0.0008 & 1.0151 & 0.0008 & 0.055 \\
\hline 11 & BVIC & 0.0002 & 1.0036 & 0.0002 & 0.0509 \\
\hline 12 & BBRI & 0.0039 & 1.0796 & 0.0037 & 0.0496 \\
\hline 13 & PNBN & 0.0006 & 1.0127 & 0.0006 & 0.0484 \\
\hline 14 & BNLI & 0.0029 & 1.0735 & 0.0027 & 0.0391 \\
\hline
\end{tabular}

Sumber : Data Diolah, 2016

Tabel 4. Proporsi Dana Masing-Masing Saham pada Model Indeks Tunggal (periode 2007-2010).

\begin{tabular}{|c|c|c|c|c|c|c|}
\hline No & Saham & $\frac{B_{1}}{\sum_{2}}$ & $\frac{\overline{\mathbf{R}}_{1}-\mathbf{R}_{F}}{\beta_{1}}$ & $\frac{\overline{\mathrm{R}}_{1}-\mathrm{R}_{\mathrm{F}}}{\beta_{1}}-\mathrm{C}^{*}$ & $\mathrm{Z}_{1}$ & $\mathrm{X}_{1}$ \\
\hline 1 & BABP & 0.5635 & 1.0341 & 1.0314 & 0.58 & $4.13 \%$ \\
\hline 2 & BEKS & 1.9719 & 0.2765 & 0.2738 & 0.54 & $3.84 \%$ \\
\hline 3 & NISP & 4.0887 & 0.1776 & 0.175 & 0.72 & $5.09 \%$ \\
\hline 4 & MEGA & 10.9032 & 0.1768 & 0.1741 & 1.9 & $13.50 \%$ \\
\hline 5 & BKSW & 6.0065 & 0.1556 & 0.1529 & 0.92 & $6.53 \%$ \\
\hline 6 & BBCA & 25.0516 & 0.0999 & 0.0972 & 2.43 & $17.31 \%$ \\
\hline 7 & BMRI & 18.5968 & 0.0805 & 0.0778 & 1.45 & $10.29 \%$ \\
\hline 8 & BBNI & 13.756 & 0.0757 & 0.073 & 1 & $7.14 \%$ \\
\hline 9 & BNGA & 12.6801 & 0.0705 & 0.0679 & 0.86 & $6.12 \%$ \\
\hline 10 & INPC & 11.6549 & 0.055 & 0.0524 & 0.61 & $4.34 \%$ \\
\hline 11 & BVIC & 5.1267 & 0.0509 & 0.0482 & 0.25 & $1.76 \%$ \\
\hline 12 & BBRI & 28.852 & 0.0496 & 0.0469 & 1.35 & $9.63 \%$ \\
\hline 13 & PNBN & 10.7886 & 0.0484 & 0.0458 & 0.49 & $3.51 \%$ \\
\hline 14 & BNLI & 26.2797 & 0.0391 & 0.0364 & 0.96 & $6.80 \%$ \\
\hline
\end{tabular}

Sumber: Data diolah, 2016 
Pada tabel 3 ditunjukkan perhitungan Cut-off Rate dan penyeleksian saham yang akan dimasukkan ke dalam portofolio optimal pada saat terjadinya krisis keuangan global tahun 2007 - 2010. Ketentuan dari saham yang ingin dibentuk kedalam portofolio optimal adalah bahwa nilai Excess Return to beta harus lebih besar dari nilai Cut of Rate (ERB > Ci). Dapat dilihat pada tabel di atas bahwa semua kandidat saham memiliki nilai ERB lebih besar dari nilai Cut Of point. Maka keseluruhan saham pada tabel tersebut dapat dibentuk ke dalam portofolio optimal. Setelah diketahui besaran nilai ERB terhadap nilai Cut of Rate (Ci) dapat ditentukan nilai $C u t$ of Point $\left(\mathrm{C}^{*}\right)$ yang diambil dari nilai Cut Of Rate (Ci) terakhir dari saham yang ternasuk dalam pembentukan portofolio optimal.

Tabel 4 menunjukkan besarnya proporsi dana yang di investasikan untuk setiap saham yang terdapat di dalam portofolio optimal saat terjadinya krisis keuangan global (tahun 2007-2010). Dapat dilihat pada tabel di atas, dari 14 saham portofolio optimal proporsi dana paling besar ditujukan pada saham BBCA (PT.Bank Central Asia,tbk) sebesar $17.31 \%$. hal itu berarti dari $100 \%$ proporsi dana investasi, sebesar $17.31 \%$ di investasikan kepada saham BBCA (PT.Bank Central Asia,tbk), selanjutnya $13.50 \%$ pada saham MEGA (PT.Bank Mega,tbk), $10.29 \%$ kepada saham BMRI (PT.Bank Mandiri,Tbk), $9.63 \%$ pada saham BBRI (PT.Bank Rakyat Indonesia,tbk), $7.14 \%$ pada saham BBNI (PT.Bank Negara Indonesia,tbk), 6.80\% pada saham BNLI (PT.Bank Permata,tbk), $6.53 \%$ pada saham BKSW (PT.Bank QSB Kesawan,tbk), 6.14\% pada saham BNGA (PT.Bank Niaga Indonesia,tbk), $5.09 \%$ pada saham NISP (PT.Bank OCBC
NISP,tbk), 4.34\% pada saha INPC (PT.Bank Artha Graha International,tbk), $4.13 \%$ pada saham BABP (PT.Bank ICB Bumiputera,tbk), 3.84\% pada saham BEKS (PT.Bank Pundi Indonesia,tbk), 3.51\% pada saham PNBN (PT.Bank Pan Indonesia,tbk), dan tingkat proporsi dana terkecil untuk diinvestasikan adalah saham BVIC (PT.Bank Victoria,tbk) sebesar $1.76 \%$.

Tabel 5. Return dan Risiko Portofolio Sebelum Menggunakan Solver

Return Portofolio Risiko Portofolio

$\frac{1.82 \%}{\text { Sumber : Data Diolah, }}$

Berdasarkan pada tabel 5 ditunjukkan portofolio optimal yang terbentuk sebelum menggunakan solver adalah return portofolio sebesar $1.82 \%$ dan risiko portofolio sebesar $5.84 \%$. Hasil dari kinerja portofolio optimal diatas akan dioptimalisasi kembali dengan fasilitas solver.

Tabel 6. Return dan Risiko Portofolio Sebelum Menggunakan Solver

\begin{tabular}{ll}
\hline Return Portofolio & Risiko Portofolio \\
\hline $1.87 \%$ & $5,29 \%$ \\
\hline
\end{tabular}

Sumber : Data Diolah

Terdapat perbedaan penurunan risiko portofolio setelah menggunakan solver sebesar $1.23 \%$, hal itu berarti dengan menggunakan solver risiko portofolio saham dapat diminimalisasi berdasarkan ketentuan-ketentuan penggunaan solver yang telah disebutkan. Sedangkan return portofolio terdapat peningkatan return sebesar $0.05 \%$, karena tujuan dari penggunan solver adalah untuk meminimalisasi risiko dengan tingkat return tertentu.

Tabel 7. Perbandingan Return dan Risiko Saat terjadinya Krisis Keuangan Global Saham Sebelum dan Setelah Menggunakan Solver

\begin{tabular}{llcccc}
\hline No & Periode & $\begin{array}{c}\text { Return } \\
\text { sebelum Solver }\end{array}$ & $\begin{array}{c}\text { Return setelah } \\
\text { 20 }\end{array}$ & $\begin{array}{c}\text { Rolver } \\
\text { Risiko sebelum } \\
\text { Solver }\end{array}$ & $\begin{array}{c}\text { Risiko setelah } \\
\text { Solver }\end{array}$ \\
\hline 1 & $\begin{array}{l}\text { Saat terjadinya krisis } \\
\text { keuanganglobal (2007-2010) }\end{array}$ & $1.82 \%$ & $1.87 \%$ & $6.52 \%$ & $5.29 \%$ \\
\hline
\end{tabular}

Sumber: Data diolah, 2016 
Tabel 7 menunjukkan perbedaan tingkat return dan risiko portofolio optimal saham saat terjadinya krisis keuangan global. Return portofolio setelah solver nilainyalebih besar dari return portofolio sebelum solver pada periode yaitu sebesar $0,05 \%$. Pada periode saat terjadinya krisis keuangan global terdapat peningkatan return sebesar $0.05 \%$ menjadi $1.87 \%$ setelah menggunakan Solver, karena berdasarkan ketentuan-ketentuan yang telah ditetapkan pada solver yaitu untuk meminimalisasi risiko pada tingkat return tertentu. Untuk risiko portofolio optimal nilainya berubah dari portofolio sebelum optimalisasi $6.52 \%$ dapat diminimalkan menjadi $5.29 \%$. Hal ini menunjukkan bahwa dengan menggunakan solver, risiko portofolio optimal pada Model Indeks Tunggal dapat lebih diminimalkan.

\section{Kesimpulan}

Terdapat 14 saham yang membentuk portofolio optimal dengan Model Indeks Tunggal saat terjadinya krisis keuangan global. Pada Model Indeks Tunggal, saat terjadinya krisis keuagan global 14 saham-saham yang membentuk portofolio antara lain saham BABP, saham BEKS, saham NISP, saham MEGA, saham BKSW, saham BBCA, saham BMRI, saham BBNI, saham BNGA, saham INPC, saham BVIC, saham BBRI, saham PNBN dan saham BNLI.

Pembentukan portofolio optimal dari saham-saham perbankan dengan Model Indeks Tunggal pada periode krisis keuagan global menghasilkan return portofolio sebesar $1.87 \%$ dan risiko portofolio yang siap ditanggung sebesar $5.29 \%$. Hal tersebut terjadi karena pada saat krisis keuangan global, saham-saham perbankan yang tercatat di Bursa Efek Indonesia mengalami resesi dan penurunan.

\section{Daftar Pustaka.}

Bussines \& Management Journal Bunda Mulia no.1, 2008. Analisis Portofolio Optimal Saham-Saham LQ45 pada periode Agustus 20052006 dengan Menggunakan Single Indeks Model di Bursa Efek Indonesia.
Darmaji T \& Fakhruddin H.M 2006. Pasar Modal di Indonesia (Edisi 2). Jakarta: Salemba Empat.

Elton, E.J, and Grubber, 1995, Modern Portfolio Theory and Invesment Analysis 5thed, John Wiley \& Sons, New York.

Fabozzi, Frank J. (1999). ManajemenInvestasi. BukuSatu. Jakarta: Salemba Empat.

Habib, Aril. 2008. KiatJituPeramalanSaham, AnalisisdanTeknikal.Yogyakarta, Andi offset.

Husnan, Suad, 1998, Dasar-dasar Teori Portofolio dan Analisis Sekuritas, Edisi Pertama, Yogyakarta, UPP AMP YKPN.

Husnan, Suad, 2001, Dasar-dasar Teori Portofolio dan Analisis Sekuritas, Edisi Ketiga, Yogyakarta, UPP AMP YKPN.

Husnan, Suad, 2003, Dasar-dasar Teori Portofolio dan Analisis Sekuritas, Edisi Kelima, Yogyakarta, UPP AMP YKP

Jogiyanto, 2000, Teori Portofolio dan Analisis Investasi, Edisi Kedua, Yogyakarta: Penerbit BPFE.

Jogiyanto. 2003. Teori Portofolio dan Analisis Investasi. Edisis Ketiga. Yogyakarta :BPEE UGM

Jogiyanto. 2009. Teori Portofolio dan Analisis Investasi. Edisis Keenam. Yogyakarta :BPEE UGM

Kamaruddin Ahmad, 2004. DasarDasarManajemenInvestasiedisi

4.RinekaCipta. Jakarta

Kasmir. 2002. Manajemen Perbankan. Cetakan Ketiga. PT Raja Grafindo Persada. Jakarta

Ketut Rindjin. 2000. Pengantar Perbankan dan Lembaga Keuangan Bukan Bank. PT Gramedia Pustaka Utama. Jakarta

Markowitz, M. Harry, 1959, Portfolio Selection, Journal of Finance, pp 77-91

Markowitz, M. Harry, 1959, Portfolio Selection: Efficient Diversification ofInvestment, The John Wiley and Son, Inc. 
Markowitz, M. Harry, Michael R.Tobin and A. Lintner, 1967, Portfolio Selection,Journal of Finance and Accounting

Mohamad Samsul. 2006. Pasar Modal dan Manajemen Portofolio, Jakarta: Erlangga

Ramadhan Aryasandi, 2012. Pembentukan Portofolio Optimal Saham-Saham Perbankan dengan Menggunakan Model Indeks Tunggal dan Constant Correlation Model.

Riska Rosdiana, 2010. Analisis Optimalisasi Portofolio Saham Syariah (Pada Jakarta Islamic Indeks Tahun 20062010)

Sugiyono.(2010). MetodePenelitianBisnis. Bandung: CV Alfabeta.

Sumariyah, 1997, Teori Portofolio: Pengantar Pengetahuan Pasar Modal, UPPAMPN YKPN, Yogyakarta.

Sharpe, William F. 1963. A Simplied Model for Portfolio Analysis, Management Science Journal
Sunaryah, 2003.Pengetahuan Pasar Modal, Yogyakarta: UPP AMP YKPN

Sari Yuniarti, 2010. Pembentukan Portofolio Optimal Saham-Saham Perbankan dengan Menggunkan Model Indeks Tunggal.

Tendelilin, Eduardus, 2007. Analisis Investasi dan Manajemen Portofolio. Edisi ketujuh, Yogyakarta: BPFE.

Umanto Eko, 2008. Analisis dan Penilaian Kinerja Portofolio Optimal Saham $L Q 4$

Widoatmodjo, S. 2005. Cara Sehat Investasi di Pasar Modal. Edisi Revisi. ElexMedia Komputindo. Jakarta

www.idx.co.id/JSXStatistics/MONTHLY/tab id/183/language/id-ID/Default.aspx

www.finance.yahoo.com,

http://hadiborneo.wordpress.com/2013/

07/15/penentuan-portofoliooptimal-single-index- model.

http://id.wikipedia.org/wiki/Bursa_Efek_Ind onesia,

www.bi.go.id. 